\title{
The effect of meniran extract (Phyllanthus niruri $L$.) addition on viscosity, foam overrun, foam stability and foam's microscopic of nano whey protein isolate
}

\author{
Winda Fransisca Saragih ${ }^{1 *}$, Abdul Manab ${ }^{2}$, Manik Eirry Sawitri ${ }^{2}$, Premy Puspitawati \\ Rahayu $^{2}$, and Ria Dewi Andriani ${ }^{2}$ \\ ${ }^{1}$ Master Student of Animal Science, Universitas Brawijaya, Jl. Veteran, Malang 65145, East Java, \\ Indonesia \\ ${ }^{2}$ Lecturer of Animal Science, Universitas Brawijaya, Jl. Veteran, Malang 65145, East Java, Indonesia
}

\begin{abstract}
Meniran is an Indonesian herbal plant which has health benefits due to its bioactive compounds. It can be applied to food product, whey protein isolate, were easily absorbed for body. The purpose of this research was to determine the effect of meniran extract addition to nano whey protein isolate on viscosity, foam overrun, foam stability and foam's microscopic. Data collection method was laboratory experiment with 4 treatments of different meniran extract addition levels which consisted of P0 (without meniran extract), P1 (30 ug/mL), P2 (60 ug/mL) and P3 (90 $\mathrm{ug} / \mathrm{mL}$ ) which repeated 3 replications respectively. Experiment was designed by Completely Randomized Design (CRD). The data was analyzed using Analysis of Variance (ANOVA), if there were significantly differences, it would be continued by Duncan Multiple Range Test (DMRT). The results showed that meniran extract addition to nano whey protein isolate gave significant effect $(\mathrm{P}<0.05)$ on viscosity. However, there was no effect on foam overrun and stability. It is concluded that the addition of meniran extract P3 $(90 \mathrm{ug} / \mathrm{mL})$ to nano whey protein isolate resulted in viscosity and foam's microscopic (stable, uniform and thick).
\end{abstract}

\section{Introduction}

Proteins are heterogeneous macromolecules with various structural (primary, secondary, tertiary, quaternary). The primary structure of protein related to peptide bonds between amino acid components and sequence in their molecule. Proteins consist of five categories namely casein, whey, milk fat globule membrane, enzymes and other minor proteins [1]. The main components of milk protein are casein $(80 \%)$ and whey $(20 \%)$. Whey protein is a by-product of dairy processing or casein production. It consists of $\alpha$-lactalbumin ( $\alpha$-LA, $20 \%$ ), $\beta$-lactoglobulin ( $\beta$ - Lg, 50\%), bovine serum albumin (BSA, 10\%), immuno-globulins $(10 \%)$ and peptones protease $(<10 \%)[2]$.

* Corresponding author: windafsaragih@student.ub.ac.id 
Whey proteins have high solubility, viscosity through water binding, gelling, emulsifying, fat binding, foam forming and able to improve the milk's color, taste and texture [3]. Whey protein component that has good viscosity and foam-forming properties is $\beta$-lactoglobulin [3], [4]. Foam formation is affected by materials adsorption on the airwater surface and the ability to decrease surface tension. Polyphenols decrease surface tension because of interaction hydrophobic groups of amino acids, therefore optimal foam formed. Another advantage of polyphenols addition is foam stabilization [5].

Meniran is an Indonesian herbal plant that has health benefits, such as antioxidant and immunomodulator. Bioactive compounds of meniran consist of alkaloid, flavonoid, phenolic, phyllanthin, saponin, steroid and tannin [6]. They can be obtained using microwave-assisted extraction (MAE) method by organic solvent and microwaves. The advantages of MAE are used solvent minimally, time efficiently and environmentally friendly. Besides health benefits, the application of meniran in food products can improve the functional properties of whey protein through covalent and non-covalent binding (hydrophobic interactions, van der Walls and hydrogen bonds). Based on the description above, it was carried out to evaluate the effect of meniran extract addition with different concentration treatments to determining functional properties on viscosity, foam overrun, foam stability and foam's microscopic of whey protein isolate.

\section{Materials and methods}

\subsection{Materials}

The materials used for this research were meniran powder that was obtained from Balai Materia Medica Batu (Malang, East Java), Whey Protein Isolate (WPI) 90 was obtained from local market. $\mathrm{NaN}_{3}$ and aquadest were obtained from Panadia Laboratory (Malang, East Java). The equipment used were microwave at level medium high power $\left(70^{\circ} \mathrm{C}\right)$ (Sharp Model R - 222Y(S)), hotplate stirrer (SBS), optical microscope (Olympus CX21FS1), viscometer (Brookfield DV3TLVCJ0), mini hand mixer (Seniora) and filter paper (Whatman No. 4).

\subsection{Methods}

The research methodology was laboratory experiment using a Completely Randomized Design (CRD) with four different treatments containing meniran extract (control, $30 \mathrm{ug} / \mathrm{mL}$, $60 \mathrm{ug} / \mathrm{mL}$ and $90 \mathrm{ug} / \mathrm{mL})(\mathrm{w} / \mathrm{v})$ which repeated three replications respectively.

\subsubsection{Meniran Extraction And Evaporation}

Meniran extraction was described by [7] using Microwave-Assisted Extraction (MAE) method. Meniran powder $3 \mathrm{~g}$ in $100 \mathrm{~mL}$ aquadest was macerated for 24 hours. After that, meniran solution was extracted with Microwave-Assisted Extraction method at $70^{\circ} \mathrm{C}$ for 10 minutes (one minute radiation, two minutes off and so on) and filtered by filter paper Whatman No.4. The extract $(10 \mathrm{~mL})$ was evaporated at $50^{\circ} \mathrm{C}$ for 6 minutes using microwave evaporator. The final form of the extract had dry and crumbly texture.

\subsubsection{Interaction of Whey Protein Isolate (WPI) and Meniran Extract}

Five grams of WPI were heated using a hotplate stirrer at $65-70^{\circ} \mathrm{C}$ for 40 minutes. After that, meniran extract was gently added according to treatments until reached $100 \mathrm{~mL}$ 
volume. The addition of meniran extract changed functional properties on viscosity, foam overrun, foam stability and foam's microscopic of whey protein isolate.

\subsubsection{Viscosity}

Viscosity was analysed according to [8] procedure with slight modification using Viscometer Brookfield. Sample was taken as much as $100 \mathrm{~mL}$ and analysed at $37^{\circ} \mathrm{C}$ and 20 rpm for 20 seconds using spindle No.40. The result was observed and recorded.

\subsubsection{Foam Overrun and Stability}

Foam overrun was determined using [9] method. Sample was taken as much as $20 \mathrm{~mL}$ and placed into measure glass $100 \mathrm{~mL}$, homogenized using mini hand mixer for 3 minutes and waited for 30 seconds. Foam overrun result ready to be observed. After that, the foam was waited for 30 minutes to continue foam stability analysis. The results of foam overrun and stability was measured by formula:

$$
\text { Foam Overrun }(\%)=\frac{\mathrm{Vt}}{\mathrm{V} 0} \times 100 \%
$$

Description: $\quad \mathrm{V} 0=$ Total volume before stirring $(\mathrm{mL})$

$\mathrm{Vt}=$ Total volume after stirring $(\mathrm{mL})$

$$
\text { Foam Stability }(\%)=\frac{\mathrm{Vt}}{\mathrm{V} 0} \times 100 \%
$$

Description: $\quad \mathrm{V} 0=$ Total volume before stirring $(\mathrm{mL})$

$\mathrm{Vt}=$ Total volume after stirring and waiting 30 minutes $(\mathrm{mL})$

\subsubsection{Foam's Microscopic}

Foam's microscopic analysis was done based on [7] procedure using optic microscope. Sample $(20 \mathrm{~mL})$ was homogenized for 60 seconds, placed the foam on object glass and covered with cover glass. Optical microscopy was observed and photographed at 40x and 100x magnification.

\subsection{Statistical Analysis}

The data for viscosity, foam overrun and foam stability were analyzed by analysis of variance (ANOVA) was carried out using the Microsoft Excel Software. The data for foam's microscopic was analyzed descriptively and compared to data published in literature. The level of significance was determined at $\mathrm{P}<0.05$.

\section{Results and discussion}

\subsection{Viscosity}

The addition of meniran extract (control, $30 \mathrm{ug} / \mathrm{mL}, 60 \mathrm{ug} / \mathrm{mL}$ and $90 \mathrm{ug} / \mathrm{mL}$ ) gave different effects $(\mathrm{P}<0.05)$ on viscosity (Table 1$)$. Whey protein isolate without meniran extract $(\mathrm{P} 0)$ has high viscosity at $10,42 \mathrm{cP}$ because protein is a food ingredient that has good solubility and viscosity properties. High viscosity indicates the strength of water-binding. But, the research of meniran extract addition on whey protein isolate decreased solubility and 
viscosity because of complex form between proteins and polyphenols, mainly formed by hydrophobic interactions and hydrogen bonds. It has an impact a change conformation of them and predicted decrease in viscosity of whey protein-meniran solution. [10] explained high viscosity has a high protein content because water-soluble protein form globules, which is hydrophobic inside and hydrophilic outside with a larger water-binding capacity. The water-binding capacity can be affected by cohesion forces include density and distance intermolecular. The high cohesion of whey protein was comparable to high water-binding capacity; thus, the flow solution becomes low.

Heating process of whey protein solution at $65-70^{\circ} \mathrm{C}$ causes change in protein structure to become open, that can interact with polyphenols from meniran through hydrogen bonds. The interaction between whey protein and polyphenols meniran reduces viscosity. It is assumed that more addition of meniran extract result more intensive changes, especially in conformation change of whey protein and polyphenols; decrease surface hydrophobicity due to interaction between whey protein and phenolic compounds. The interaction thought to reduces water holding capacity and hydrophobic interaction in whey protein molecules, resulting decrease in whey protein flowability. [11] explained that protein and polyphenols form a complex structure, generally formed by hydrophobic interaction and hydrogen bonds, thus change the conformation of protein-polyphenols and decrease surface hydrophobicity. [12] reported that temperature during the heating process of whey protein is very affecting to their structures, too high temperature can make $\beta$-lactoglobulin denaturation which can reduce viscosity.

Table 1. The average viscosity of whey protein added with meniran extract

\begin{tabular}{|c|c|}
\hline Treatment $(\mathbf{u g} / \mathbf{m L})$ & Average \pm SD (cP) \\
\hline 0 & $10.42^{\mathrm{b}} \pm 0.87$ \\
\hline 30 & $5.30^{\mathrm{a}} \pm 1.57$ \\
\hline 60 & $7.50^{\mathrm{ab}} \pm 2.75$ \\
\hline 90 & $4.21^{\mathrm{a}} \pm 2.32$ \\
\hline
\end{tabular}

Description: The addition of meniran extract with different concentrations to whey protein gave significant effect $(\mathrm{P}<0.05)$.

\subsection{Foam Overrun}

The results of foam overrun in Table 2 indicate that the addition of meniran extract (control, $30 \mathrm{ug} / \mathrm{mL}, 60 \mathrm{ug} / \mathrm{mL}$ and $90 \mathrm{ug} / \mathrm{mL}$ ) did not give significant effect. It could be due to low concentration of meniran extract. The more concentration of meniran extract to whey protein impact more decrease foam overrun. Sample P3 with meniran extract $90 \mathrm{ug} / \mathrm{mL}$ had the lowest percentage of form overrun. [13] described meniran bioactive compounds will interact with amino acids through non-covalent bond interactions consisting of hydrophobic interactions, van der Waals, hydrogen bridges and ionic bonds. However, it contrasts to the statement given by [14] that interaction between $\beta$ lactoglobulin and polyphenols will form biopolymer film which reduces surface tension and increases foam overrun.

Whey protein was a surfactant because it was able to reduce surface tension and has foaming properties through intermolecular interaction due to the stirring process. Whey protein without meniran extract gave highest percentage of foam overrun at $325,83 \%$, there is no interaction to food ingredients, thus protein structures were stable with hydrophobic 
groups lead to air-phase and hydrophilic to water-phase. [15], [16] reported whey protein contributes to foam formation by diffusing and concentrating on the air-liquid interface, which reduces surface tension.

Another determining factor of foam overrun analysis is processing and stirring time. Sample was placed as much as $20 \mathrm{~mL}$ to measure cup $100 \mathrm{~mL}$ and stirred for 3 minutes using a mini hand mixer. [17] explained that the optimal time for protein agitation was 3 minutes. When the stirring duration is continued until 8 minutes, the foam overrun will decrease drastically because of hand mixer agitation.

\subsection{Foam Stability}

Data of foam stability are presented in Table 2. Foam stability is foam analysis to maintain foam formed, it is continuing of foam overrun. Foam stability occurs when the air on molecular cavity is persistent and no bubble collapse. [16] described the interaction between amino acids and polyphenols were increasing foam stability due to surface hydrophobicity decrease.

WPI is a good foam-forming agent, however not always stable, this research was done to improve foam stability by the addition of meniran extract containing phenolic compounds. This research aimed to improve interfacial properties and foam stability. [18] reported the addition of polyphenols on WPI can increase foam stability 1.9-2.1 times compared to WPI only.

Temperature and humidity were external factor to stabilized foam. In this study, foam stability was analysed at $28^{\circ} \mathrm{C}$ of room temperature and $65 \%$ of humidity. According to [19], foam stability was identified by bubble collapse against the temperature and humidity. When dried environment, the bubble collapse rate is higher than wet environment.

Table 2. The average foam overrun and stability of whey protein added with meniran extract

\begin{tabular}{|c|c|c|}
\hline Treatment (ug/mL) & Foam Overrun (\%) & Foam Stability (\%) \\
\hline 0 & $325.83 \pm 1.44$ & $233.33 \pm 14.43$ \\
\hline 30 & $325.00 \pm 0.00$ & $225.83 \pm 1.44$ \\
\hline 60 & $325.00 \pm 0.00$ & $225.00 \pm 0.00$ \\
\hline 90 & $317.50 \pm 12.99$ & $234.17 \pm 13.77$ \\
\hline
\end{tabular}

Description: The addition of meniran extract with different concentrations to whey protein did not give significant effect.

\subsection{Foam's Microscopic}

Foam's microscopic was observed to find out shape and distribution foam at 40x and 100x magnification using an optic microscope, which is presented in Figure 1. These observations showed different result, respectively. Sample without meniran extract (P0) had a larger shape and uneven distribution foams. Increasing concentrations of meniran extract result in uniform shape and spread foams equally. [14] reported that the addition of polyphenols on protein will result in hydrophobic interactions and elasticity surface film. The decrease of elasticity surface film throughout foaming showed stable and firm bubbles which characterized by decrease of foam's volume after stirring process. 
Increasing polyphenols induce air pressure on the small bubbles (Fig. A2 with triangle line) will diffuse to the larger bubbles (Fig. C2 with ellipse line) and develop foams almost uniform (Fig. D2 with circle line). [20], [21] explained the increasing concentrations of polyphenols from tea leaves extract and carrageenan were able to change the protein structures and thick the film which led to stability of protein structures. In certain thicknesses of film layer, it collapse and merge bubbles because of molecules' surface adsorption.

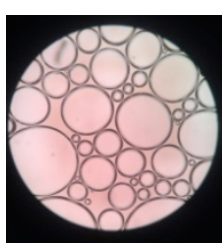

A1

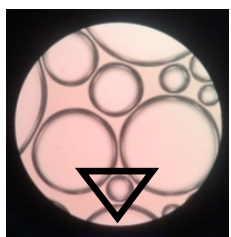

A2

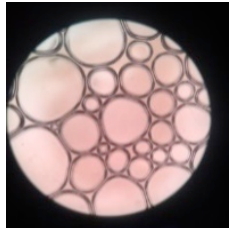

B1

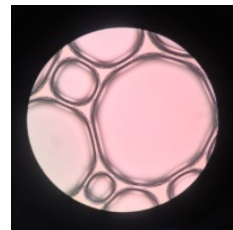

B2

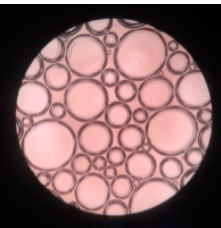

$\mathrm{C} 1$

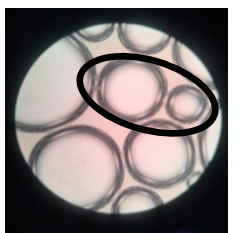

$\mathrm{C} 2$

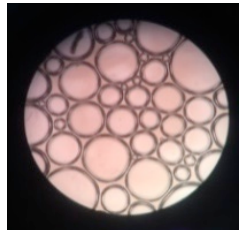

D1

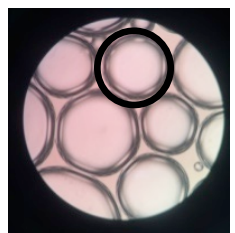

D2

Figure 1. Optical Microscopy Whey Protein Isolate-Meniran

Description: A1 (control), B1 (30ug/mL), C1 (60 ug/mL), D1 (90ug/mL) observed at 40x magnification;

A2 (control), B2 (30ug/mL), C2 (60 ug/mL), D2 (90ug/mL) observed at 100x magnification

\section{Conclusion}

Based on the results showed that meniran addition can reduce viscosity because a change conformation of proteins and polyphenols' form and decrease surface hydrophobicity. The combination between whey protein isolate-meniran extract has improve the foams microscopic. The significant result was obtained on P3 $(90 \mathrm{ug} / \mathrm{mL})$ that has viscosity at $4,21 \mathrm{cP}$, foam overrun at $317,50 \%$, foam stability at $234,17 \%$ and foam's microscopic (stable, uniform and thick).

The acknowledgment of this study was supported by Penelitian Penerimaan Negara Bukan Pajak (PNBP) 2020, Universitas Brawijaya.

\section{References}

1. A. Manab, M. E. Sawitri, and K. U. A. Awwaly (UB Press, Malang, Indonesia, 2017).

2. C. Harna, C. M. Kusharto, and K. Roosita, Media Kesehat. Masy. Indones., 13/4, 354361 (2017).

3. R. F. Hutama and R. Andoyo, Prosiding Seminar Nasional Fakultas Pertanian UNS, 39-46 (2019).

4. R. I. Baeza, C. C. Sanchez, J. M. R. Patino, and A. M. R. Pilosof, E. Dickinson (Ed.), Food Colloids: Interactions Microstructure and Processing. (The Royal Society of Chemistry, Cambridge, UK, 2005). 
5. S. D. Rodríguez, M. Von Staszewski, and A. M. R. Pilosof, Food Hydrocoll., 50, 108115 (2015).

6. H. Rivai, R. Septika, and A. Boestari, J. Farmasi Higea, 5(2), 15-23 (2013).

7. P. P. Rahayu, L. E. Radiati, and A. Manab, Curr. Res. Nutr. Food Sci. J., 3(3), 224-236 (2015).

8. M. Abughoush, M. Al-Mahasneh, M. Samhouri, M. Al-Holy, and T. Herald, Int. J. Food Eng., 4(7), 1-13 (2008).

9. M. Zheng, Z. B. Jia, and J. X. Jiang, Adv. J. Food Sci. Technol., 6(2), 238-240 (2014).

10. Z. Herceg and V. Lelas, J. Food Eng., 66(4), 433-438 (2005).

11. C. Li, T. Dai, J. Chen, X. Li, T. Li, C. Liu, D. J. McClements, Food Chem., 339, 128145 (2021).

12. S. El-Shibiny, A. F. Farrag, G. El-Garawany, and F. M. Assem, Int. J. Dairy Sci., 2, 196-206 (2007).

13. K. Nagy, M. Courtet-Compondu, G. Williamson, S. Rezzi, M. Kussmann, and A. Rytz, Food Chem., 132(3), 1333-1339 (2012).

14. M. Von Staszewski, V. M. P. Ruiz-Henestrosa, and A. M. R. Pilosof, Food Hydrocoll., 35, 505-511 (2014).

15. X. Xiong, M. T. Ho, B. Bhandari, and N. Bansal, Int. Dairy J., 109, 104758 (2020).

16. Y. Cao, Y. L. Xiong, Y. Cao, and A. D. True, Food Hydrocoll., 82, 379-387 (2018).

17. C. A. Padiernos, S.-Y. Lim, B. G. Swanson, C. F. Ross, and S. Clark, J. Dairy Sci., 92, 3049-3056 (2009).

18. J. T. Diaz, E. A. Foegeding, and M. A. Lila, Food Funct., 11(6), 5091-5104 (2020).

19. X. Li, S. I. Karakashev, G. M. Evans, and P. Stevenson, Langmuir, 28(9), 4060-4068 (2012).

20. C. D. Kanakis, I. Hasni, P. Bourassa, P. A. Tarantilis, M. G. Polissiou, and H. TajmirRiahi, Food Chem., 127(3), 1046-1055 (2011).

21. Z. Wang, S. Zhang, and B. Vardhanabhuti, J. Food Sci., 80(8), 1893-1902 (2015). 